сфері України / Д. М. Стеченко, I. В. Безуглий // Науковий вісник Чернігівського державного інституту економіки і управління. Серія 1 : Економіка. - 2014. - Вип. 2. - С. 9-18.

13. Стратегічний розвиток туристичного бізнесу:монографія /[Ткаченко T.I., Мельниченко С. В. , Бойко М. Г. та ін.]; за заг. ред. А. А. Мазаракі. - К.: Київ. нац. торг.екон. ун-т, 2010. - 596 с.

14. Бордун О. Стан та перспективи транспортного забезпечення туристичної індустрії Львівської області// Наукові записки. №2. 2011. ( Рекреаційна географія і туризм), c. $147-152$.

15. Медвідь Л. І. Транспортна інфраструктура як важливий чинник розвитку туристичної галузі регіону// Режим доступу:http://geopolitika.crimea.edu/arhiv/

2014/ tom10-v-2/029 medv.pdf.

16. Пікулик О. Б. Пріоритетні напрями розвитку транспортної системи Західного регіону України в умовах європейської інтеграції / О.Б. Пікулик . // Науковий . вісник Волинського національного університету ім. Лесі Українки. - 2008. - № 7. - С. 284-291. (Серія : Економічні науки).

17.Транспорт i зв'язок Закарпаття (Статистичний збірник)//Державна служба статистики України. Головне управління статистики у Закарпатській області, Ужгород $-2015,88 \mathrm{c}$.

Експерт редакційної колегії к.е.н., дочент УкрДУЗТ Полякова О.М.

УДК 005.934:33

\title{
УДОСКОНАЛЕННЯ ПРИНЦИПІВ ФОРМУВАННЯ ТА ФУНКЦІОНУВАННЯ НАГЛЯДОВИХ РАД В СИСТЕМІ ЕКОНОМІЧНОЇ БЕЗПЕКИ ПІДПРИЕМСТВА
}

\author{
Котов А. М., к.е.н., доцент, \\ Мозгова Л. О., к.е.н, \\ Іваніснко В.В. к.е.н., професор (ХНЕУ)
}

Розглянуто принципи формування наглядової ради та необхідність трансформачії ключових ї̈ компетенцій у зв'язку з рухом корпорачії по стадіях життевого ииклу. Виявлено необхідність поступового переходу від простої структури наглядової ради до більш складної через врегулювання виникаючих конфліктів в управлінні. Розвиваючи механізми формування $i$ функиіонування наглядової ради запропоновано використовувати ряд принцииів внутрішньої взаємодії членів ради.

Ключові слова: акціонерні товариства, корпоративне управління, економічна безпека, наглядова рада, структура, формування, життєвий цикл, загрози, принципи.

\section{СОВЕРШЕНСТВОВАНИЕ ПРИНЦИПОВ ФОРМИРОВАНИЯ И ФУНКЦИОНИРОВАНИЯ НАБЛЮДАТЕЛЬНЫХ СОВЕТОВ В СИСТЕМЕ ЭКОНОМИЧЕСКОЙ БЕЗОПАСНОСТИ ПРЕДПРИЯТИЯ}

\author{
Котов А. Н., к.э.н, доцент, \\ Мозговая Л. А., к.э.н., \\ Иваниенко В. В., к.э.н., профессор (ХНЭУ)
}

Рассмотрены принщииы формирования наблюдательного совета и необходимость трансформации ключевых ее компетенщий в связи с движением корпорачии по стадиям жизненного иикла. Выявлена необходимость постепенного перехода от простой структуры 
наблюдательного совета к более сложной через урегулирование возникающих конфликтов в управлении. Развивая механизмь формирования и функиионирования наблюдательного совета, предложено использовать ряд принципов внутреннего взаимодействия членов совета.

Ключевые слова: акционерные общества, корпоративное управление, экономическая безопасность, наблюдательный совет, структура, формирование, жсизненный цикл, угрозы, принципь.

\title{
IMPROVING THE PRINCIPLES OF FORMATION AND FUNCTIONING OF THE SUPERVISORY BOARDS IN THE SYSTEM OF ECONOMIC SECURITY
}

\author{
Kotov A.M., PhD., Associate Professor, \\ Mozgova L.O., PhD., \\ Ivanienko V.V., PhD., Professor ( KNUE)
}

One of improving corporate governance is to increase the efficiency of its internal mechanisms, including the person deserves attention supervisory board. Revealed that ensure economic security entity is a complex economic, organizational, informational, analytical and methodical task to create favorable conditions for economic activity of the entity. It was determined that one of the following conditions are and effectiveness of corporate governance. The principles of formation of the Supervisory Board and the need to transform its core competencies in connection with the movement of the corporation for the stages of the life cycle. Identified the need for a gradual transition from the simple structure of the Supervisory Board in a more complex through the settlement of conflicts that arise in the management. Developing mechanisms for the formation and functioning of the Supervisory Board proposed to use a number of principles of internal interaction of board members.

Keywords: corporation, corporate governance, economic security, the supervisory board, the structure, formation, life cycle, threats principles.

Постановка проблеми. Ефективна модель корпоративного управління $\epsilon$ важливим компонентом забезпечення економічної безпеки та сталого розвитку вітчизняних підприємств. Одним 3 напрямів удосконалення корпоративного управління $\epsilon$ підвищення ефективності функціонування його внутрішніх механізмів, серед яких особливої уваги заслуговує наглядова рада. Нині наглядові ради на багатьох вітчизняних підприємствах відіграють досить формальну роль. Це призводить до недооцінки цього органу управління в системі економічної безпеки.

Аналіз останніх досліджень. Незважаючи на збільшення в останні роки кількості наукових публікацій та досліджень в рамках тематики корпоративного управління: у працях I. В. Белікова [1] (проблеми взаємодії між акціонерами, менеджментом, радою директорів і стейкхолдерами), А. В. Бухвалова [2], М. Дженсена [3], С. П. Кукури [4], Т. В. Момот [5], С. Майєрса [6] (загальні проблеми корпоративного управління, взаємодії акціонерів і менеджменту), А. Д. Радігіна [7] (зміни якісного рівня корпоративного управління, особливостей акціонерної власності та корпоративного контролю), Л. С. Ружанської [8] (принципи формування, внутрішні елементи і процеси в раді директорів, технології роботи питання підвищення ефективності роботи ради директорів), К. Фами [9] (пошук кореляції між роботою ради директорів i фінансовими результатами роботи компаніiі), багато аспектів залишаються недостатньо повно освітленими.

Виділення невирішених частин загальної проблеми. Разом 3 тим, недостатньо вивчені основні елементи механізму роботи ради директорів (наглядової ради), питання зміни ролі та функцій ради директорів в сучасний період, функції формування стратегії, особливостей діяьності та ролі ради директорів в системі економічної безпеки. Практично відсутні комплексні дослідження ключових факторів ефективності механізму діяльності ради директорів i 
процесу оцінки діяльності ради. Все це визначає необхідність і значимість подальших досліджень у цих та інших напрямках.

Формування цілей статті

(постановка завдання). Враховуючи вищесказане необхідно переходити до глибокого переосмислення принципів формування та функціонування наглядових рад, що передбачає перехід від рад, заснованих на структурі та лояльності, до рад, заснованих на ефективності і володіні необхідним рівнем компетенцій i професіоналізму. Отже, ціллю $\epsilon$ розробка комплексу заходів і практичних рекомендацій щодо вдосконалення механізму діяльності наглядової ради у системі економічної безпеки підприємства.

\section{Виклад основного матеріалу.}

Забезпечення економічної безпеки господарюючого суб'єкта $є$ складним економічним, організаційним, інформаційноаналітичним та методичним завданням щодо створення сприятливих умов економічної діяльності господарюючого суб'єкта. Однією 3 таких умов $\epsilon$ й ефективність системи корпоративного управління. Розглядаючи корпоративне управління в системі економічної безпеки підприємства, до основних іiі елементів рекомендують віднести: об'єкти системи (акціонерне товариство, акціонерна власність); суб'єкти системи (акціонери, керівництво акціонерного товариства; служба економічної безпеки акціонерного товариства; органи державного регулювання; саморегулівні організації, фінансові посередники); правове регулювання (нормативно-правові акти; внутрішні положення та інструкціï); функціональні складові системи (фінансова, корпоративна, правова, майнова, кадрова, технологічна, інформаційно-аналітична та інформаційнопсихологічна, екологічна); механізм реалізації економічної безпеки діяльності акціонерного товариства (організаційний; економічний); методологія комплексної оцінки стану системи безпеки діяльності акціонерного товариства (методика оцинки стану корпоративного управління, методика оцінки ефективності публічного розміщення акцій; методика оцінки впливу загроз на економічну безпеку діяльності акціонерного товариства).

Під корпоративним управлінням ми розуміємо комплексну систему взаємодії між виконавчими органами, наглядовою радою, акціонерами та іншими групами зацікавлених осіб 3 метою гармонізації корпоративних відносин та здійснення управління і контролю над корпорацією, а також отримання прибутку. Згідно ст. 51 Закону України «Про акціонерні товариства» [10] наглядова рада акціонерного товариства $\epsilon$ органом, що здійснює захист прав акціонерів товариства і в межах компетенції, визначеної статутом та цим Законом, контролює та регулює діяльність виконавчого органу.

Відповідно до закону онтогенезу (будьяка система проходить у своєму розвитку наступні стадії: зародження, зростання, зрілість, згасання), кожне підприємство проходить через певні етапи розвитку. Наглядова рада, будучи частиною підприємства, також проходить через декілька етапів, кожному 3 яких притаманні певні способи формування та характеристики функціонування. На даних етапах існують певні аспекті діяльності ради, що несуть у собі загрози економічній безпеці підприємства.

Історія розробки концепції життєвих циклів розвитку організації починається 3 1965 року і робіт Дж. Гарднера. Перша модель розвитку організації з'явилася в 1967 році, авторами іï були Г. Ліппітт і У. Шмідт. Далі йшов розвиток, поглиблення і специфікація уявлень про організаційний розвиток і в міру накопичення емпіричних і теоретичних даних з'являлися все нові і нові моделі. В якості основи було обрано моделі Грейнера i Адізеса: перша розглядає розвиток організації через зміну еволюційних етапів, друга продовжує цю ідею, припускаючи, що динаміка організаційного розвитку носить циклічний характер, концентруючи увагу на двох найважливіших параметрах життєдіяльності організації: гнучкості та контрольованості (керованості) [11].

У цьому контексті розглядаються принципи формування наглядової ради та необхідність трансформації ключових іiі компетенцій у зв'язку з рухом корпорації по стадіях життєвого циклу. Це передбачає поступовий перехід від простої структури наглядової ради до більш складної через врегулювання виникаючих конфліктів в управлінні. Таким чином, на 1 стадії наглядова рада як орган управління може бути відсутнім (у разі створення корпорації), може 
існувати ліше формально (практика приватизованих пидприємств). Ризики на данному етапі притаманні саме формально існуючим радам, оскільки непрацездатність органу корпоративного контролю, однією із функцій якого $є$ узгодження інтересів учасників корпоративних відносин (як наслідок, є механізмом попередження корпоративних конфліктів), несе в собі загрози економічній безпеці підприємства.

На 2 стадії формується рада, в якій рішення приймаються під впливом мажорітарного акціонера, який найчастіше $\epsilon$ головою ради. Для цього етапу існують ризики, повязані із власністю (проблема прійняття узгодженого рішення, порушення прав міноритарних акціонерів, проблеми виплати дивідендів тощо). Як наслідок, корпоративні конфлікти, судові позови, негативний вплив на імідж пидприємства та його ринкову вартість.

На 3 стадії закладається основа професійної ради, шляхом залучення фахівців, що володіють необхідними ключовими професійними компетенціями в процесі прийняття управлінських рішень, в тому числі i незалежних членів. Даний етап несе у собі загрози відсутності процедури декларування членами наглядової ради своєї афілійованості та наявності положення, що регламентує діяльність цього органу, неякісного відбору членів наглядової ради, відсутності ефективної та прозорої системи відбору та оцінки й, як наслідок, винагороди членів ради. Це збільшує можливість виникнення корпоративних конфліктів на підприємстві та послаблює контрольованість наглядової ради.

На 4 стадії у зв'язку 3 розвитком підприємства i збільшення складності i кількості, розглянутих радою питань, основним завданням цього етапу є створення більш ускладненої структури наглядової ради - комітетів. Зазначений етап може супроводжуватись загрозами, що притаманні 3 стадії, а також відсутністю чіткого розмежування функцій між комітетами або відсутністю комітетів взагалі, що призводить до зниження контролю над менеджментом. Комітети можуть виступати у якості: фільтрів при прийнятті рішень щодо пропозицій, що виносить менеджмент на розгляд наглядової ради; посилювачів контролю над діяльністю менеджменту (наприклад, комітет iз закупівель, з операційної діяльності); буферів між менеджментом та наглядовою радою (пидвіщення відповідальності менеджменту та покращення контакності 3 вищім керівництвом без втручання ради у компетенцію менеджменту).

На 5 стадії у зв'язку з ускладненням діяльності підприємства відбувається посилення впливу невизначених зовнішніх факторів впливу, які змушують акціонера посилювати внутрішній і зовнішній контроль i координацію діяльності ради, шляхом зміни принципів його формування i функціонування. Наглядова рада повинна не тільки адекватно враховувати можливий вплив зазначених чинників, але також залежно від стадії життєвого циклу компанії, складності виникаючих питань, рівня їхньої стратегічності та важливості для компанії, ранжувати їх за ступенем значущості для прийняття найбільш ефективних рішень.

Розвиваючи механізми формування i функціонування наглядової ради, пропонується висувати такі вимоги до самої наглядової ради та іiі членів: критерії відбору членів наглядової ради при висуванні на посаду повинні враховувати не тільки ступінь довіри акціонера до кандидатів, але й здатності останнього до стратегічного мислення, вирішенню складних управлінських проблем, їх прихильності корпорації i iii цінностям; при відборі кандидатів у даний орган управління необхідно передбачити деяку кількість членів ради, які працюватимуть на постійній основі протягом усього року (необхідно враховувати фактичну можливість членів ради приділяти час для очних засідань та роботи в комітетах); для ефективної взаємодії всередині ради, іiі члени повинні володіти високим інтелектуальним рівнем, професійними компетенціями i володіти незалежним судженням (є певною гарантією прийнятяя зважених, неангажованих рішень 3 урахуванням «зовнішнього» погляду; незалежні директори повинні складати не менше $1 / 3$ всіх членів ради і очолювати комітети наглядової ради 3 кадрів і винагород, з аудиту); при формуванні ради директорів слід враховувати особливості етапу на якому знаходиться компанія, рівень взаємодії основних груп акціонерів, ради i виконавчих органів, ступінь дисперсності акціонерного капіталу, наявність великих 
власників акцій, їх афільованість між собою і можливість блокування для проведення єдиної стратегіï по консолідації владних опосередкованих повноважень; по мірі зростання корпорації і переходу на наступні етапи життєвого циклу компанії необхідно здійснювати трансформацію наглядової ради через зміну необхідних ключових компетенцій, підвищення інституційного статусу і корпоративне навчання.

Висновки даного дослідження i перспективи подальших робіт у цьому напрямку. Щоб створити ефективну наглядову раду слід збільшити ऑï роль в процесі формування та затвердження стратегіï, можливості контролю за іiі реалізацією. Насамперед це стосується затвердження політики економічної безпеки. Узагальнюючи дане дослідження, можна припустити, що підвищення ефективності функціонування вітчизняних корпорацій в значній мірі залежить від принципів формування та функціонування наглядових рад. Перспективою подальших досліджень є розробка методики оцінки механізму діяльності наглядової ради на основі ключових показників ефективності (життєвий цикл, структура, процеси, культура і функції).

\section{СПИСОК ЛІТЕРАТУРИ}

1. Бєліков I. В. Власники та менеджери / I. В. Бєліков // Журнал для акціонерів. 2000. - № 8. - C. 7-14.

2. Бухвалов А. В. Корпоративное управление как объект научных исследований / А. В. Бухвалов // Российский журнал менеджмента. - 2005. - Т.3, № 3. - С. 81-96.

3. Jensen $M$. Theory of the Firm:
Managerial Behavior, Agency Costs and Ownership Structure / M. Jensen, W. Meckling // Journal of Financial Economics. - 1976. - Vol. 3. - № 4. - P. 305-360.

4. Кукура С. П. Теория корпоративного управления / С. П. Кукура. - М.: ЗАО «Издательство экономика», 2004. - 478 с.

5. Момот Т. В. Вартісно-орієнтоване корпоративне управління: від теорії до практичного впровадження / Т. В. Момот. - Х. : ХНАМГ, 2006. - $380 \mathrm{c}$.

6. Myers S. Determinants of Corporate Borrowing / S. Myers // Journal of Financial Economics. - 1977. - Vol. 5. - № 2. - P. 147175.

7. Радыгин А. Д. Корпоративное управление и защита прав собственности: эмпирический анализ и актуальные направления реформ / А. Д. Радыгин, P. М. Энтов. - М.: 2001. -270 с.

8. Ружанская Л. С. Развитие совета директоров как внутреннего механизма корпоративного управления / Л. С. Ружанская // Корпоративные финансы. - 2007. - № 4 (4). - C. 14-33.

9. Fama E. Agency Problems and Residual Claims / E. Fama, M. Jensen // Journal of Law and Economics. - 1983. - Vol. 26. June. -№ 2. P. 327-349.

10. Закон Украины «Об акционерных обществах» от 17 сентября 2008 года № 514VI // «Налоги и бухгалтерский учет». Будущее акционерных обществ. - 13.11.2008 г. - № 91 (1171). - С. 2-43.

11. Модели развития организации модель Л. Грейнера [Електронний ресурс]. Режим доступу : URL : http://www.classs.ru/stati/predprinimatelstvo/mo deli_razvitija.html. - Назва з екрану.

Рецензент д.е.н., професор ХНЕУ Пилипенко А.А. Експерт редакційної колехії к.е.н., доцент УкрДУЗТ Зубенко В.О. 